\title{
Plasma oxytocin concentrations during the menstrual cycle in the rhesus monkey, Macaca mulatta
}

\author{
J. Falconer*†, M. D. Mitchell*, L. A. Mountford*, and J. S. Robinson*† \\ *Nuffield Department of Obstetrics and Gynaecology, John Radcliffe Hospital, Headington, \\ Oxford OX3 9DU, and $\uparrow N$ uffield Institute for Medical Research, Headley Way, Headington, \\ Oxford OX3 9DS, U.K.
}

\begin{abstract}
Summary. Plasma samples were obtained from 8 conscious rhesus monkeys at 3-4 day intervals throughout the menstrual cycle. Oxytocin concentrations were significantly higher in mid-cycle (Days 10-11) than at Days 4-5 $(P<0.01)$ and Days 28-29 $(P<0.02$, Wilcoxon signed rank test $)$. No significant correlations between oxytocin and oestradiol or progesterone were found.
\end{abstract}

\section{Introduction}

Since the advent of specific and sensitive radioimmunoassays for oxytocin (Chard, 1973), attention has been concentrated on the role of oxytocin in human pregnancy (Dawood, Raghavan, Pociask \& Fuchs, 1978), whilst changes in oxytocin during the menstrual cycle have not been reported.

The present study was therefore undertaken to investigate the changes in oxytocin during the menstrual cycle in the rhesus monkey, a primate which has a menstrual cycle very similar to that of women.

\section{Materials and Methods}

Blood samples were obtained from the saphenous vein by venepuncture from 8 conscious female rhesus monkeys at 3-4 day intervals throughout the menstrual cycle using a method previously described (Elvidge, Challis, Robinson, Roper \& Thorburn, 1976). Blood was collected into chilled heparinized syringes, centrifuged at $4^{\circ} \mathrm{C}$ and $1500 \mathrm{~g}$ for $15 \mathrm{~min}$ and the plasma was stored at $-15^{\circ} \mathrm{C}$ until assayed. Oxytocin concentrations in these samples were measured using a sensitive and specific radioimmunoassay (Mitchell, Mountford, Natale \& Robinson, 1980). This assay was based on the method of Dogterom, Van Wimersma Griedanus \& Swaab (1977) and used their antiserum and standards. The lower limit of sensitivity of this assay was $0.8 \pm 0.1 \mathrm{pg}$ (mean \pm s.e.m., $n=20$ ) and the intra- and inter-assay variations were 9.4 and $13.9 \%$ respectively. Progesterone and oestradiol levels in these samples were also determined, using previously described materials and procedures (Challis, Davies \& Ryan, 1973; Challis et al., 1977). The characteristics of the antibodies used have also been described (Furr, 1973). The lower limits of sensitivity of both assays were $<10 \mathrm{pg}$. The intra- and inter-assay variations for the progesterone assay were 6.7 and $8.1 \%$ respectively while for the oestradiol assay they were 9.2 and $19.4 \%$ respectively.

The stage of the cycle for each sample was assessed from the progesterone levels and the results were grouped accordingly. It was only possible to establish the day of the cycle to within $1-2$ days. 


\section{Results}

Although the variations were large, oxytocin concentrations increased at mid-cycle and there was an indication of 2 peaks (Text-fig. 1a). The increased oxytocin concentrations occurred after the pre-ovulatory rise in oestradiol (Text-fig. 1b) although oxytocin concentrations continued to increase while oestradiol levels were falling. Oxytocin levels remained high until progesterone concentrations were nearly maximal (Text-fig. $1 \mathrm{~b}$ ) but started to fall before the progesterone peak was reached. No significant correlations between oxytocin and oestradiol or progesterone were found.

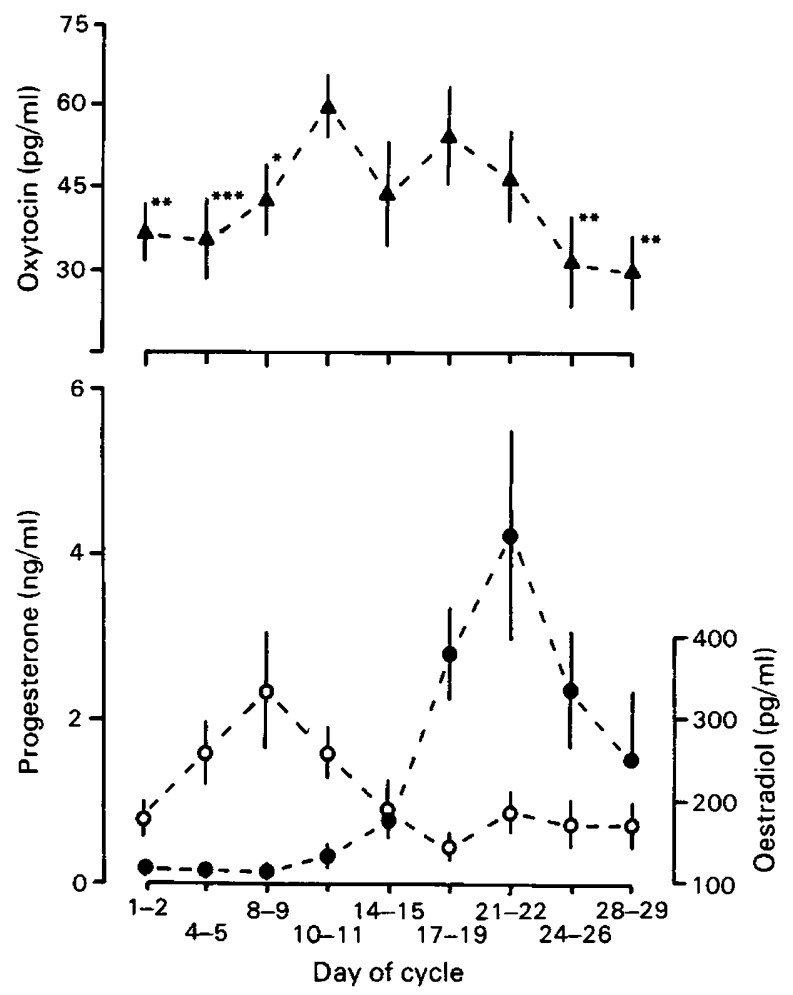

Text-fig. 1. Mean \pm s.e.m. (for 7-8 samples) plasma concentrations of (a) oxytocin and (b) oestradiol $(O)$ and progesterone $(O)$ in rhesus monkeys during the menstrual cycle (see text). Oxytocin values that are significantly different from that on Days $10-11$ are indicated: ${ }^{*} P<$ $0.05 ;{ }^{* *} P<0.02 ;{ }^{* * *} P<0.01$ (Wilcoxon signed rank test).

\section{Discussion}

The present finding of high concentrations of oxytocin in mid-cycle is in agreement with previous studies in rats in which pituitary content (Crowley, O’Donohue, George \& Jacobowitz, 1978) and release (Konig, Pitzel \& Bischoff, 1979) of oxytocin are highest at mid-cycle. Plasma levels of neurophysin I, which has been suggested to be associated with oxytocin (Robinson, 1975), are also elevated in mid-cycle in rhesus monkeys and show a broader peak than LH or oestrogen (Robinson, Ferin \& Zimmerman, 1976).

Although the release of neurophysin has been shown to be stimulated by oestrogen (Robinson et al., 1976), oxytocin values remained high while oestradiol levels declined, and a 
role in ovulation may be the reason. Treatment of rabbits with oxytocin antiserum inhibits ovulation (Roca et al., 1978) and oxytocin inhibits the hypothalamic enzyme(s) that degrades gonadotrophin-releasing hormone (GnRH) (Griffiths \& Hooper, 1974). The mid-cycle oestrogen may therefore stimulate the production of oxytocin which inhibits GnRH degradation and so makes more GnRH available for stimulation of LH (Robinson et al., 1976).

The continued high levels of oxytocin may be related to luteolysis. Exogenous oxytocin stimulates luteolysis and shortens cycle length in the cow (Hansel \& Wagner, 1960) and immunization against oxytocin prolongs the ovine oestrous cycle (Flint, Mitchell \& Sheldrick, 1979). Oxytocin will also stimulate the production of prostaglandin F-2 $\alpha$, which is considered to be the luteolytic agent (McCracken, Barcikowski, Carlson, Green \& Samuelsson, 1972) released by the sheep uterus. This process may be facilitated by the earlier rise in oestrogen since it has been shown that oestrogen will increase the number of high-affinity binding sites for oxytocin in the uterus (Soloff, 1975). However, in the rhesus monkey the oxytocin concentrations declined before maximal progesterone levels were reached, perhaps giving support to observations in the goat that the oxytocin release following vaginal distension is decreased when progesterone levels are high (Roberts \& Share, 1969; Roberts, 1975).

The plasma oxytocin concentrations during the menstrual cycle are higher than those found in pregnant monkeys (Mitchell et al., 1980), but this may be related to the different states of the animals in the two studies, conscious monkeys in this study and anaesthetized pregnant monkeys in the other.

We thank Dr J. Dogterom and Dr D. F. Swaab (Institute for Brain Research, Amsterdam) for gifts of antiserum and authentic standard, $\mathrm{Mr} \mathrm{H}$. Elvidge and his staff for excellent assistance with the monkey colony and Mrs J. Arnold for typing the manuscript. M.D.M. is an M.R.C. Senior Fellow. This work was supported by the M.R.C.

\section{References}

Challis, J.R.G., Davies, I.J. \& Ryan, K.J. (1973) The concentrations of progesterone, estrone and estradiol-17 $\beta$ in the pregnant rhesus monkey. Endocrinology 93, 971-973.

Challis, J.R.G., Hartley, P., Johnson, P., Patrick, J.E., Robinson, J.S. \& Thorburn, G.D. (1977) Steroids in the amniotic fluid of the Rhesus monkey (Macaca mulatta). J. Endocr. 73, 355-363.

Chard, T. (1973) The radioimmunoassay of oxytocin and vasopressin. J. Endocr. 58, 143-160.

Crowley, W.R., O'Donohue, T.L., George, J.M. \& Jacobowitz, D.M. (1978) Changes in pituitary oxytocin and vasopressin during the estrous cycle and after ovarian hormones: evidence for mediation by norepinephrine. Life Sciences 23, 2579-2586.

Dawood, M.Y., Raghaven, K.S., Pociask, C. \& Fuchs, F. (1978) Oxytocin in human pregnancy and parturition. Obstetrics and Gynaecology 51, 138-143.

Dogterom, J., Van Wimersma Greidanus, T.B. \& Swaab, D.F. (1977) Evidence for the release of vasopressin and oxytocin into cerebro-spinal fluid: measurements in plasma and C.S.F. of intact and hypophysectomized rats. Neuroendocrinology 24, $108-118$.

Elvidge, H., Challis, J.R.G., Robinson, J.S., Roper, C. \& Thorburn, G.D. (1976) Influence of handling and sedation on plasma cortisol in Rhesus monkeys (Macaca mulatta). J. Endocr. 70, 325-326.
Flint, A.F.P., Mitchell, M.D. \& Sheldrick, E.L. (1979) Delayed luteal regression in ewes immunized against oxytocin. J. Physiol., Lond. 269, 85-86.

Furr, B.J.A. (1973). Radioimmunoassay of progesterone in peripheral plasma of the domestic fowl in various physiological states and in follicular venous plasma. Acta endocr., Copenh. 72, 89-100.

Griffiths, E.C. \& Hooper, F.C. (1974) Competitive inhibition between oxytocin and luteinizing hormonereleasing factor (LRF) for the same enzyme in the rat hypothalamus. Acta endocr., Copenh. 75, 435-442.

Hansel, W. \& Wagner, W.C. (1960) Luteal inhibition in the bovine as a result of oxytocin injections, uterine dilation, and intrauterine infusions of seminal and preputial fiuids. J. Dairy Sci. 43, 796-805.

Konig, A., Pitzel, L. \& Bischoff, Ch. (1979) Cycle dependence of in vitro oxytocin release from posterior pituitary lobes of female rats. Acta endocr., Copenh., Suppl. 225, 206, Abstr.

McCracken, J.A., Barcikowski, B., Carlson, J.C., Green, K. \& Samuelsson, B. (1972) The physiological role of prostaglandin $F_{2 \alpha}$ in corpus luteum regression. Adv. Biosci. 9, 599-624.

Mitchell, M.D., Mountford, L.A., Natale, R. \& Robinson, J.S. (1980) Concentrations of oxytocin in the plasma and amniotic fluid of Rhesus monkeys (Macaca mulatta) during the latter half of pregnancy. $J$. Endocr. (in press). 
Roberts, J.S. (1975) Cyclical fluctuations in reflexive oxytocin release during the estrous cycle of the goat. Biol. Reprod. 13, 314-317.

Roberts, J.S. \& Share, L. (1969) Effects of progesterone and estrogen on blood levels of oxytocin during vaginal distention. Endocrinology 84, 1076-1081.

Robinson, A.G. (1975) Isolation, assay and secretion of individual human neurophysins. J. clin. Invest. 55, 360-367.

Robinson, A.G., Ferin, M. \& Zimmerman, E.A. (1976) Plasma neurophysin levels in monkeys: emphasis on the hypothalamic response to estrogen and ovarian events. Endocrinology 98, 468-475.

Roca, R.A., Garofalo, E.G., Martino, I., Piriz, H., Rieppi, G., Marafi, M., Ohahian, C. \& Gadola, L. (1978) Effects of oxytocin antiserum and of indomethacin on HCG-induced ovulation in the rabbit. Biol. Reprod. 19, 552-557.

Solof, M.S. (1975) Uterine receptor for oxytocin: effects of estrogen. Biochem. Biophys. Res. Commun. 65, $205-212$.

Received 7 September 1979 